DOI: $10.17805 /$ trudy.2019.1.2

\title{
ОСОБЕННОСТИ РАЗВИТИЯ ИСТОРИКО-ПСИХОЛОГИЧЕСКОГО НАПРАВЛЕНИЯ НА ФАКУЛЬТЕТЕ ПСИХОЛОГИИ МОСКОВСКОГО ГУМАНИТАРНОГО УНИВЕРСИТЕТА (1993-2018)
}

\author{
И. С. Алексеенко
}

Московский гуманитарный университет

Аннотация: В статье анализируются особенности развития историко-психологического направления на кафедре общей психологии и истории психологии московского гуманитарного университета.

По материалам научного доклада на конференции «Кросс-культурные и междисциплинарные исследования в истории психологии: результаты и перспективы» (Москва, 24-25 ноября 2018 г.), проведенной в рамках проекта № 18-513-18017, поддержанного РФФИ.

Ключевые слова: история психологии; преподавание истории психологии; историко-психологические исследования; кафедра психологии; образовательный стандарт; Московский гуманитарный университет

\section{PECULIARITIES OF THE DEVELOPMENT OF THE HISTORICAL AND PSYCHOLOGICAL FIELD AT THE FACULTY OF PSYCHOLOGY, MOSCOW UNIVERSITY FOR THE HUMANITIES (1993-2018)}

\author{
I. S. Alekseyenko \\ Moscow University for the Humanities
}

Аннотация: The article analyzes the peculiarities of the development of historical and psychological field at the Department of General Psychology and History of Psychology, Moscow University for the Humanities.

The research is based on the materials of the scientific report at the conference "CrossCultural and Interdisciplinary Studies into the History of Psychology: Results and Prospects" (Moscow, 24-25 November 2018), held within the project No. 18-513-18017 supported by RFBR.

Ключевые слова: history of psychology; teaching history of psychology; historical and psychological research; department of psychology; educational standard; Moscow University for the Humanities

Развитие историко-психологического направления является одним из приоритетных направлений в общепсихологических исследованиях, осуществляемых на факультете психологии и социальной работы. Роль таких исследований неоспоримо велика, так как именно история психологии, 
являясь памятью науки, способна не только объективно сохранить и воспроизвести знания, накопленные в ходе исторического развития психологической науки, но и предвидеть ее дальнейшее развитие. Значение таких исследований важно с точки зрения научного труда любого уровня и любой тематики, будь курсовая, выпускная квалификационная работа, магистерская или кандидатская диссертация, статья, ведь приступая к изучению той или иной проблемы, мы всегда обращаемся к истории ее разработки.

Д. Шульц и С. Шульц, говоря о «влиянии истории психологии на психологию в целом», проводят аналогию, как «прошлое науки самым непосредственным образом воздействует на ее настоящее. Например, психологи, изучающие поведение, также признают влияние прошлого на настоящее. Они полагают, что поведение определяется предшествующими условиями жизни и укоренившимся опытом - иными словами, текущее состояние человека можно объяснить прошлым» (Шульц Д., Шульц С., 1998: 15). Кроме того, историко-психологические исследования устанавливают и междисциплинарные связи психологии с другими науками.

С другой стороны, исследования историко-психологического характера достаточно сложны. Любое историческое событие, описываемое учеными, уже свершилось. Историки психологии, имеющие определенный познавательный опыт, свое мировоззрение, свою точку зрения, должны непредвзято и честно воссоздать историю в инвариантности, по возможности игнорируя субъективную оценку происходящего. Также стоит отметить, проблемы, возникающие в процессе историко-психологических исследований, обусловлены и сменой философско-методологических основ науки, произошедшей в 90-годы прошлого века. Это влечет за собой переоценку историко-психологических событий и роли исторических личностей в них.

Таким образом, с одной стороны важность, а с другой стороны сложность историко-психологических исследований определяет специфику их развития. С момента образования кафедры общей психологии и истории психологии такие исследования регулярно осуществляются обучающимися и преподавателями факультета в виде учебной и исследовательской работы.

Особое значение для развития историко-психологического направления в Московском гуманитарном университет имеет деятельность В. А. Кольцовой. Известная своими исследованиями в области теории и методологии истории психологии, источниковедения, изучения творческого наследия ученых-психологов, она внесла огромный вклад в подготовку бакалавров, специалистов, магистров и аспирантов факультета. Вера Александровна работает на кафедре с самого ее основания и до сегодняшнего времени в должности профессора. Следуя лучшим отечественным традициям системности и комплексности, они вместе с Ю. Н. Олейником создали одно 
Научные труды Московского гуманитарного университета 2019 № 1

их приоритетных научных направлений работы кафедры - «история отечественной психологии».

Важным показателем интенсивного развития историко-психологического направления в научно-исследовательской деятельности нашего вуза является организация и проведение конференций «Московские встречи по истории психологии». Неизменными организаторами таких встреч являются В. А. Кольцова и Ю. Н. Олейник. Уже «II Московские встречи по истории психологии» 1995 г. были проведены с участием нашего факультета. Проведено шесть таких «встреч» и большинство из них на территории нашего вуза, и вполне закономерно, что практически все преподаватели, аспиранты и студенты кафедры включались в их организацию. Важность таких конференций трудно оспорить, так как именно такой формат научных мероприятий «...решает широкий круг задач, состоящим в обмене между учеными фундаментальными достижениями в области историко-психологических исследований, в интеграции профессионального сообщества историков психологии и объединении специалистов разных научных дисциплин вокруг актуальных проблем психологического познания, а также формировании и подготовке новых исследователей в области истории психологии. Более того, они являются своеобразным индикатором состояния психологии и науки в целом» (Журавлев, Кольцова, Олейник, 2016: 10). За время проведения конференций «Московские встречи» на нашем факультете побывали такие известные историки психологии, как А. Н. Ждан, В. В. Большакова, Д. Б. Богоявленская, Н. Л. Логинова, Е. С. Минькова, К. А. Абульханова-Славская, С. Пасс и многие другие. Такие виды взаимодействия являются важными для установления связей факультета с крупными психологическими центрами не только российскими, но и зарубежными.

За время функционирования факультета историко-психологические исследования проводились аспирантами кафедры в виде кандидатских диссертаций по различным направлениям. Так, ряд диссертаций было защищено по анализу творческого и научного пути отечественных ученых психологов: Е. А. Будиловой (Алексеенко, 2006), В. А. Вагнера (Колодкина, 2012), К. К. Платонова (Зверева, 2012). И. Н. Елисеева в своей работе рассмотрела историю развития отечественной экспериментальной психологии (Елисеева, 2015). Работа С. А. Поповой была посвящена анализу категории интуиции в отечественной и зарубежной философско-психологической мысли (Попова, 2005). Были и работы по проблематике исторической психологии: психолого-историческая реконструкция Московского купеческого общества (Федоркова, 2000), проблема реконструкции психологических характеристик личности гения на примере изучения жизненного пути творчества Ф. М. Достоевского (Холондович, 2007). 
Однако стоит отметить, что достаточно редко встречаются выпускные квалификационные работы бакалавров и магистров по историко-психологической проблематике. Это связано, прежде всего, с требованием соответствия направленности профиля и тематикой выпускных квалификационных работ. Поэтому бакалавры вовлечены в научно-исследовательскую работу через изучение учебных дисциплин «История психология» и «Историческая психология».

Методика преподавания дисциплины «История психологии» самым непосредственным образом реагирует на изменения, происходящие как в самой науке (смена философско-методических основ), так и в системе высшего образования.

Уже в первых «Требованиях к минимуму содержания и уровню подготовки выпускника по специальности 020400 - Психология» 1996 г. значилось, что выпускник должен «знать историю становления и развития психологической науки» (Государственный образовательный стандарт, 1996: Электр. ресурс) и определялось, что дисциплина изучение дисциплины «История психологии» является обязательной. Были достаточно четко прописаны дидактические единицы, которые должен освоить студент при изучении дисциплины. С появлением первого образовательного стандарта по специальности «Психология» с присвоением квалификации выпускникам «Психолог. Преподаватель психологии» в 2000 г., место дисциплины «История психологии» определилось в базовой части общепрофессионального цикла и на ее освоение отводилось достаточно большое количество часов - 180 часов. Согласно учебному плану, она изучалась в течение двух семестров на третьем курсе (для очной формы обучения) и на четвертом курсе (для студентов вечерней формы обучения). Дидактические единицы, которые должен был освоить студент при изучении дисциплины также были определены четко (Государственный образовательный стандарт, 2000: Электронный ресурс). По данному образовательному стандарту обучались студенты специальности «Психология», принятые на обучение с 2000 по 2011 г. Последний выпуск таких студентов состоялся в 2016 г. К тому же, с 2005 г. на факультете психологии началась подготовка специалистов по специальности «Педагогика и психология», стандарт которой также определял дисциплину «История психология» в качестве обязательной.

В связи с присоединением России к Болонскому процессу, в 2009 г. появляются новое третье поколение федеральных государственных образовательных стандартов бакалавров и магистров по направлениям подготовки «Психология», где дидактические единицы были заменены компетенциями. Стандарт бакалавра тогда еще содержал дисциплину «История психология» в качестве обязательной. Студенты, обучающиеся по данному стандар- 
Научные труды Московского гуманитарного университета 2019 № 1

ту, должны были знать «психологические феномены, категории методы...с позиции существующих в отечественной и зарубежной науке подходов», уметь «анализировать психологические теории...», а также в рамках научно-исследовательской деятельности изучать отечественный и зарубежный опыт по тематике исследований. (Федеральный государственный образовательный стандарт, 2011: Электр. ресурс). Новый же стандарт направлений подготовки бакалавра «Психолого-педагогическое образование» вообще исключил дисциплину «История психология» из учебного плана.

Ввиду вступления в силу Федерального Закона «Об образовании в Российской Федерации» от 29 декабря 2012 г. № 273, федеральный государственный образовательный стандарт по направлению «Психология» был вновь обновлен и исключил компетенции, напрямую связанные с дисциплиной «История психологии», тем самых поставив угрозу исключения дисциплины из учебного плана. Впереди вступление еще одной обновленной версии образовательного стандарта на основе профессиональных стандартов. Так что будущее дисциплины «История психологии» не определено. Таким образом, в связи с введением стандартов третьего поколения история психологии как учебная дисциплина претерпевает определенную трансформацию. Об этом говорит хотя бы тот факт, что если раньше дисциплина изучалась студентами в объеме 180 часов в течение двух семестров, то на сегодняшний день ее объем составляет лишь 108 часов в течение одного семестра.

Естественно, что существуют проблемы, возникающие в процессе преподавания дисциплин историко-психологического цикла, связанных и со сложностью восприятия дисциплины обучающимися. Изучение дисциплины «История психологии» требует обращения к первоисточникам, а студенты, имея возможность быстрого и легкого получения информации любого характера через Интернет, не обращаются к таковым. Они не видят связи исторического материала с практической деятельность психолога, игнорируя прогностическую функцию историко-психологических исследований. И здесь важно выстроить правильную методику преподавания, научить работать с первоисточниками, учить студентов на лекциях и семинарских занятиях анализировать историю, а не заучивать ее.

В настоящее время исследования в области история психологии продолжаются. Курс «История психологии» полностью методически обеспечен и содержательно обоснован. В соответствии с требованиями Министерства образования и науки разработаны фонды оценочных средств по дисциплине, включающие в себя методические материалы, определяющие процедуры оценивания, описаны показатели и критерии оценивания компетенций. Кроме того, разработано мультимедийное и электронное сопровождение курса.

Таким образом, характеризуя состояние историко-психологических ис- 
следований на факультете психологии и социальной работы, можно констатировать, что такие проводятся как в виде научно-исследовательской, так и в рамках учебной работы по дисциплинам историко-психологического цикла.

\section{СПИСОК ЛИТЕРАТУРЫ}

Алексеенко, И. С. (2006) Роль психологического наследия Е. А. Будиловой в развитии отечественной истории психологии : автореф. дис. ... канд. психол. наук. М. 24 с.

Государственный образовательный стандарт высшего профессионального образования. Государственные требования к минимуму содержания и уровню подготовки выпускника по специальности 020400 - Психология. (1996) [Электронный ресурс] // Портал Федеральных государственных образовательных стандартов высшего образования. URL: http://fgosvo.ru/ archivegosvpo/156/155/3/156 (дата обращения 12.01.2018).

Государственный образовательный стандарт высшего профессионального образования Специальность 020400 «Психология» Квалификация Психолог. Преподаватель психологии (2000) [Электронный ресурс] // Портал Федеральных государственных образовательных стандартов высшего образования. URL: http://fgosvo.ru/archivegosvpo/157/155/6/711 (дата обращения 12.01.2018).

Елисеева, И. Н. (2015) История развития отечественной экстремальной психологии : автореф. дис. ... канд. психол. наук. М. 25 с.

Журавлев, А. Л., Кольцова, В. А., Олейник, Ю. Н. (2016) Изучение отечественной и мировой психологической мысли: результаты и перспективы исследований // История отечественной и мировой психологической мысли: судьбы ученых, динамика идей, содержание концепций. Материалы всероссийской конференции по истории психологии «VI Московские встречи». М. : Издательство Института психологии Российской академии наук. 637 c. C. 7-15.

Зверева, Т. В. (2012) Система психологических взглядов К. К. Платонова : автореф. дис. ... канд. психол. наук. М. 20 с.

Колодкина, О. О. (2011) Вклад В. А. Вагнера в развитие разных отраслей психологии : автореф. дис. ... канд. психол. наук. М. 20 с.

Попова, С. А. (2005) Интуиция в мировой философской и психологической мысли: основные направления изучения : автореф. дис. ... канд. психол. наук. М. 34 с.

Федеральный государственный образовательный стандарт высшего профессионального образования по направлению подготовки 030300 Психология. (2011) [Электронный ресурс] // Портал Федеральных государ- 
ственных образовательных стандартов высшего образования. URL: http:// fgosvo.ru/fgosvpo/7/6/1/3 (дата обращения 12.01.2018).

Федоркова, И. Р. (2000) Психолого-историческая реконструкция Московского Купеческого Общества как субъекта предпринимательской активности : автореф. дис. .... канд. психол. наук. М. 23 с.

Холондович, Е. Н. (2010). Реконструкция психологических характеристик личности гения на примере изучения жизненного пути и творчества Ф. М. Достоевского : автореф. дис. ... канд. психол. наук. М. 23 с.

Шульц, Д., Шульц, С. Э. (1998). История современной психологии. СПб.: Издательство «Речь». 532 с.

Дата поступления: 15.01.2018 2.

Алексеенко Ирина Сергеевна - кандидат психологических наук, доцент кафедры общей психологии и истории психологии Московского гуманитарного университета. Адрес: 111395, Россия, г. Москва, ул. Юности, д. 5. Тел.: +7 (499) 374-70-34, +7 (916) 796-81-58. Эл. адрес: ialexeenko@mail.ru

Alekseenko Irina Sergeevna, Candidate of Psychology, Associate Professor, Department of General Psychology and History of Psychology, Moscow University for the Humanities. Postal address: 5, Yunosti St., Moscow, Russian Federation, 111395. Tel.: + 7 (499) 374-70-34, +7 (916) 796-81-58 E-mail: ialexeenko@mail.ru

\section{Для цитирования:}

Алексеенко И. С. Особенности развития историко-психологического направления на факультете психологии Московского гуманитарного университета (1993-2018) [Электронный ресурс] // Научные труды Московского гуманитарного университета. 2019. № 1. URL: http://journals.mosgu.ru/trudy/article/view/930 (дата обращения: дд.мм.гг.). DOI: 10.17805/trudy.2019.1.2 